\title{
Mesenteric Venous Thrombosis: Three Consecutive Cases
}

\author{
Mezenterik Venöz Tromboz: Üç Vaka Takdimi
}

\author{
Deniz Fındık', Aylin Hasanefendioğlu Bayrak², Doğan Gönüllü̈ \\ ${ }^{1}$ Sağlık Bilimleri Üniversitesi Gaziosmanpaşa Eğitim ve Araştırma Hastanesi, Genel Cerrahi Anabilim Dalı, Istanbul; ${ }^{2}$ Sağlık Bilimleri \\ Üniversitesi Gaziosmanpaşa Eğitim ve Araştırma Hastanesi, Radyoloji Anabilim Dal, İstanbul; ${ }^{3}$ Kafkas Üniversitesi Tip Fakültesi, \\ Genel Cerrahi Anabilim Dal, Kars, Türkiye
}

\begin{abstract}
Acute mesenteric venous thrombosis (MVT) has better prognosis than arterial thrombosis when the diagnosis is early. Newly developed radiological imaging are highly sensitive for of MVT; at the same time when early diagnosis is made, interventional radiology can apply aspiration thrombectomy or thrombolitics. We had presented three consecutive cases of MVT diagnosed in different clinical phases of thrombosis: first and third cases were diagnosed with intestinal necrosis, directly by laparotomy or laparoscopy and resection of the implicated segment was inevitable. Second patient was diagnosed at the phase of ischemia without necrosis, SMV was partially recanalised by the interventional radiologist with no reccurence of thrombosis for a period of 9 months.
\end{abstract}

Key words: acute mesenteric vein thrombosis; aspiration thrombectomy; hipercoagulability

\section{ÖZET}

Erken tanı konulmuș akut mezenterik venöz tromboz (MVT) olguların prognozu, akut arterial trombozlara göre daha iyidir. Görüntüleme tekniklerindeki ilerleme, MVT erken tanısına katkısı ve aynı zamanda aspirasyon trombektomi veya trombolitik uygulaması gibi noninvaziv tedavilerin uygulamasında önemlidir. Bu çalıșmada trombozun farklı klinik evrelerinde olan üç MVT vakası sunduk: birinci ve üçüncü olgulara laparotomi veya laparoskopi sayesinde bağırsak nekrozu tanısı konuldu, nekrotik kısım rezeksiyonu yapıldı. Ikinci hastaya nekrotik olmayan iskemi tanısı konuldu, girișimsel radyoloji tarafından kısmi SMV rekanalizasyonu sağlandı, takip eden dokuz ay boyunca tromboz nüks etmedi.

Anahtar kelimeler: akut mezenterik ven trombozu; aspirasyon trombektomi; hiperkoagülabilite

\section{Introduction}

Acute mesenteric venous thrombosis (MVT) is a rare condition; accounting approximately $5-10 \%$ of the cases of acute mesenteric ischemia. Mortality rate in mesenteric venous thrombosis was reported as $20-50 \%{ }^{1,2}$. In mesenteric arterial thrombosis, mortality rate is reported between $66 \%$ and $89 \%^{2}$. Thanks to the lately developed radiological imaging; early diagnosis increased and as a result; mortality rates reduced to $10-20 \%{ }^{3}$. Nowadays; non-invasive, intestine preserving approaches is more available which we would like to present our clinical experiences with three cases.

\section{Case Presentations}

\section{First Case Presentation}

A 51-year-old man with a history of hypertension and diabetes mellitus presented with progressive abdominal pain persisting for 7 days, and a new onset nausea and vomiting. Gas and stool discharge were available. Medical history showed femoral artery embolectomy ( 2 years ago) and coronary artery bypass ( 1 year ago). The patient had disused his anti-hypertensive, antidiabetic, and anti-coagulant drugs for last 6 months. Abdominal rebound tenderness localized to left lower quadrant was observed on physical examination. He was hemodinamically stable. Rectal exam revealed sour cherry coloured stool. The vital signs were stable, laboratory values were unremarkable. Abdominal computer tomography angiography (CTA) revealed partially thrombosed main portal vein (PV) and superior

IIetișim/Contact: Doğan Gönüllü, Kafkas Üniversitesi, Tip Fakültesi, Genel Cerrahi Anabilim Dal, Kars, Türkiye • Tel: 05322848741 • E-mail:dogangonullu@yahoo.com • Geliș/Received:01.03.2020 • Kabul/Accepted:04.06.2020

ORCID: Deniz Findık, 0000-0003-0823-3418 • Aylin Hasanefendioğlu Bayrak, 0000-0003-4644-6318 • Doğan Gönüllü, 0000-0002-8232-5209 


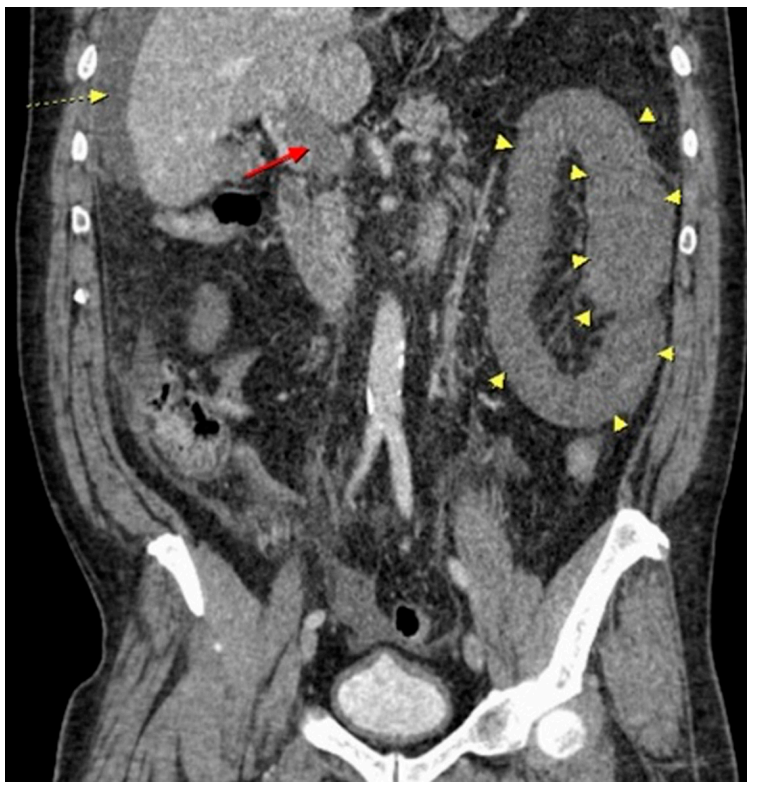

Figure 1. Coronal plane of venous phase of abdominal CTA. Thrombus in portal vein (red arrow), intestinal wall thickening and increased density of fat tissue edema (yellow arrow heads) and perihepatic free fluid (yellow dotted arrow) were depicted.

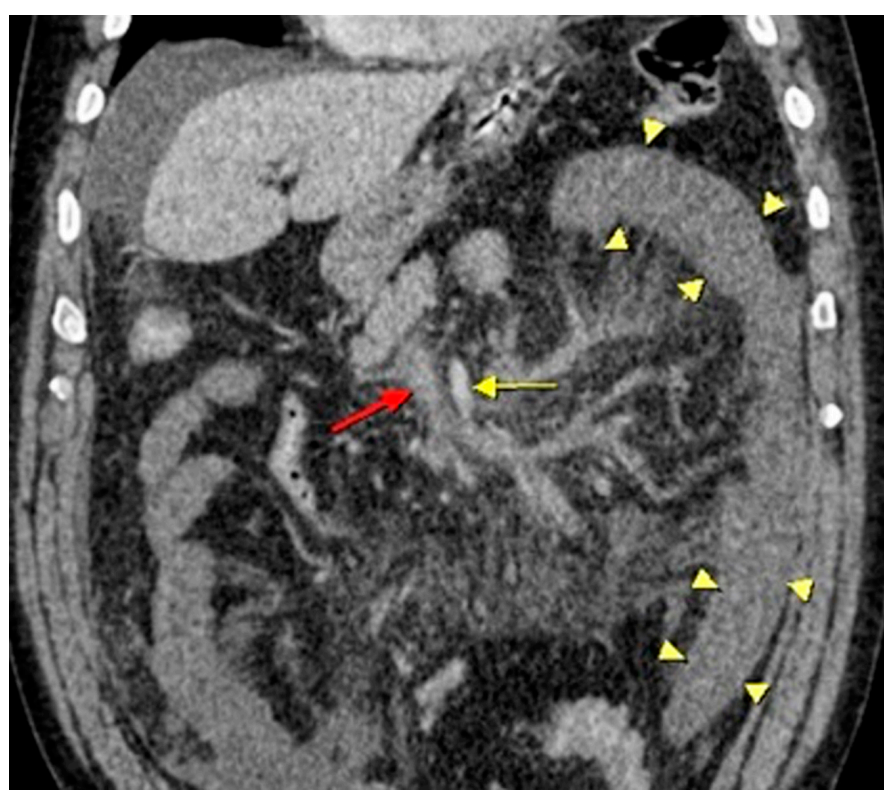

Figure 2. Coronal section taken in venous phase of abdominal CTA. Thrombus in the portal vein (red arrow), and next to that physiological contrast filling in superior mesenteric arteria (yellow arrow) were observed. Intestinal wall thickening and increased density of fat tissue edema (yellow arrow heads) were also seen. mesenteric vein (SMV). Mildly thickened intestinal walls and mesenteric fat blurring were also observed (Figure 1, 2). Oral intake was stopped. Both decompression with the nasogastric catheter and intravenous (IV) hydration with urine output monitoring were started. Wide spectrum antibiotics and low molecular weight heparin (LMWH) were applied. During follow-up, arterial blood gas $\mathrm{pH}$ was detected as 7.40 and lactate value was 5.4 unlike to initial results. He had also leukocytosis $\left(17000 / \mathrm{mm}^{3}\right)$. Therefore, emergent surgery was decided. Informed consent of the patient was obtained before the operation. The laparoscopic exploration showed diffuse ischemia, laparotomy was done immediately and approximately $100 \mathrm{~cm}$ small intestine was resected because of necrosis. End-ileostomy was performed for proximal intestines. In the postoperative first day; IV heparin started with aPTT (activated Partial Tromboplastin Time) monitoring. Intraabdominal hemorrhage developed and heparinization was stopped at 76th hour of heparinization. Patient had 6 units of erythrocyte suspension (ES) and 4 units of fresh frozen plasma (FFP) replaced. After stabilization; LMWH applied subcutaneously. After a period of 23 days, the continuity of bowel transit was restabilized. The patient was re-examined at the 12th month and there were no recurrent thrombosis of PV and SMV.

\section{Second Case Presentation}

A 44-year-old male patient presented with abdominal pain which started 4 days ago and intensified over time. Vital signs were stable, abdominal examination had diffuse tenderness. Rectal exam had normal stool. Laboratory findings were unremarkable. Abdominal CTA showed occlusive thrombosis of SMV and free intraperitoneal fluid. Patient was diagnosed as acute mesenteric ischemia and diagnostic laparoscopy was performed. Exploration showed diffuse intestinal ischemia starting from Treitz; but there was no sign of necrosis. Nasogastric decompression, IV hydration, wide-spectrum antibiotics and subcutaneously LMWH were applied. An informed consent was taken from the patient before the interventional radiology. The patient was transferred to interventional radiology department. After sedation with fentanyl, the interventional radiologist performed percutaneous transhepatic access to a branch (segment 8 ) of right portal vein with a 21-gauge Chiba needle (Argon medical devices, Dallas, Texas, USA) and placed a 6-French bright tip sheath. The distal SMV vein was accessed using different sized catheters and aspiration thrombectomy was performed 6-7 times using wide-lumen catheters (Figure 3, 4). Thrombectomy procedure has ended without any complication after recanalization of the SMV. Patient was transferred to intensive care unit 


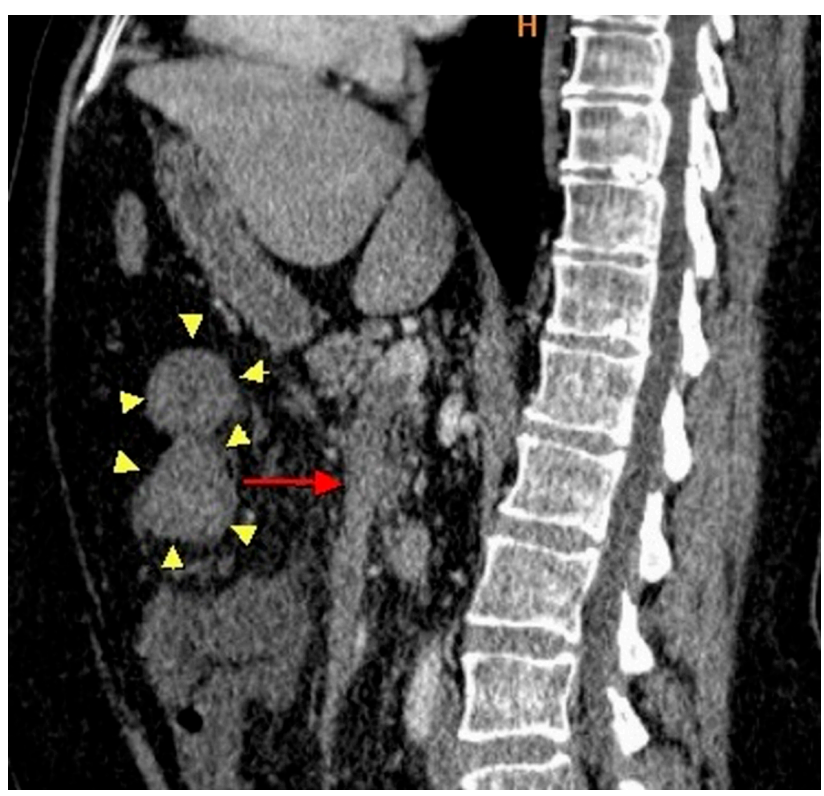

Figure 3. Sagittal section of the abdominal CTA taken in venous phase. Thrombus in the superior mesenteric vein (red arrow), and secondary changes of intestinal ischemia such as intestinal wall thickening and increased density of fat tissue edema (yellow arrow heads) were revealed.

(ICU) and heparinization was started in the next 72 hours. Three days later, abdominal CTA showed that SMV was partially re-canalized and intestinal changes were regressed. Patient was clinically stable and no longer had abdominal pain. Oral intake was started and tolerated. Gas stool discharge was available. LMWH was added to the treatment. The patient was followed for a period of 9 months with no recurrence in SMV thrombosis.

\section{Third Case Presentation}

A 34-year-old female presented with progressively increasing abdominal pain for two days, nausea and vomiting. The vital signs were stable; abdominal exam had diffuse tenderness; especially localized at upper quadrants. Patient had hematemesis and hematochezia. Laboratory tests were unremarkable. Abdominal CTA showed multiple thrombus in SMV branches and PV. IV hydration, nasogastric decompression, widespectrum antibiotics and subcutaneous LMWH were added to the treatment. During follow-up; tachycardia and clinically worsened. After the informed consent of the patient before intervention, diagnostic laparoscopy was performed. Exploration showed total necrosis starting $30 \mathrm{~cm}$ distal of Treitz ligament and continued for $100 \mathrm{~cm}$. The necrotic segment was resected and terminal ileostomy was performed for the proximal part. 160

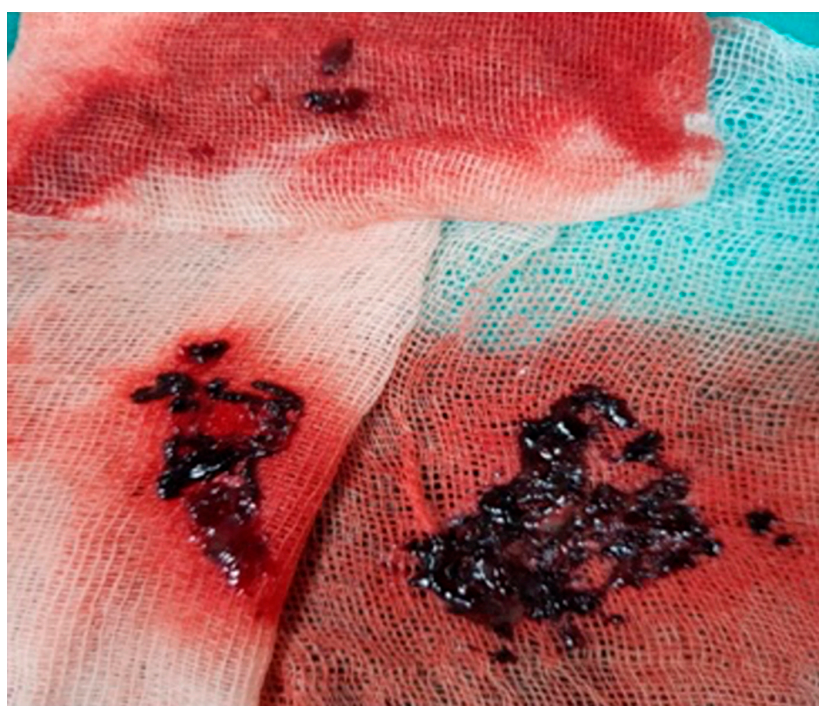

Figure 4. The blood clots extracted by percutaneous radiological intervention.

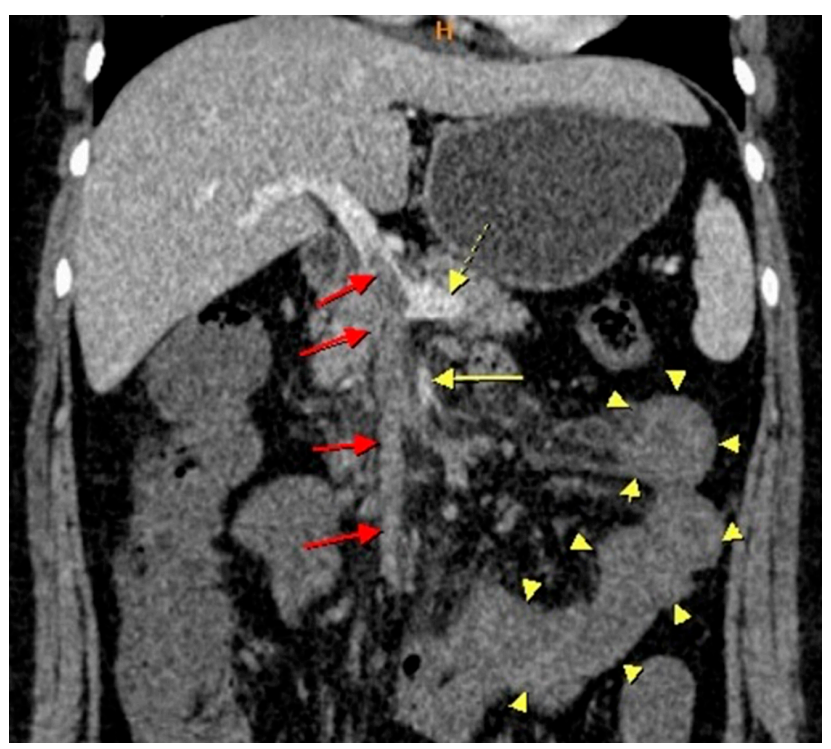

Figure 5. Coronal plane of abdominal CT taken in venous phase. Hypodense filling defect in lumen of superior mesenteric vein reaching to portal vein (red arrow), physiologic contrast filling in superior mesenteric arteria (yellow arrow) and splenic vein (yellow dotted arrow) were depicted. Intestinal wall thickening and increased density of fat tissue edema (yellow arrow heads) were also accompanied.

$\mathrm{cm}$ of ileal segment starting from ileocecal valve had ischemic changes such as walls of intestine thickened, edema occurred in fat tissue, colour changed (Figure 5). Operation ended and IV heparinization started with $80 \mathrm{iu} / \mathrm{kg}$ bolus. IV heparinization continued for 7 days. At the postoperative 5th day; explorative laparotomy performed and intestine colour seemed better. At the postoperative 11 th day; laparotomy showed the regression of the ischemic changes and intestinal colour was 
normal so intestines were anastomosed side to side. There was no recurrence in the 12 months of observational period.

\section{Discussion}

Acute MVT was first described in 1935 after resection of intestinal ischemia ${ }^{3}$. MVT has better prognosis than arterial thrombosis, especially when early diagnosis is available. It is mostly idiopathic; occurs in $21-49 \%$ of the cases ${ }^{1}$. It can occur after trauma, surgical operations (especially after splenectomy), pregnancy, oral contraceptives (9-18\%), pancreatitis, myeloproliferative diseases, protein $\mathrm{C}$ and $\mathrm{S}$ deficiencies, prothrombin and Factor Leiden 5 mutation $(4-10 \%)^{1-8}$.

Clinical suspicion is very important for diagnosis. Physical examination and laboratory tests are nonspecific; causing a delay in diagnosis. Newly developed radiological imaging techniques are highly sensitive for diagnosis of MVT; CTA show thrombus in veins, intestinal wall edema and ascites. In our cases, the diagnosis of thrombosed SMV, PV revealed by abdominal CT and was confirmed by exploratory laparotomy in case 1 , diagnostic laparoscopy in case 2 and 3 .

MVT has a high mortality rate unless there is an early diagnosis. Medical treatment includes anticoagulation, IV hydration, antibiotics, thrombolitics, thrombectomy and surgery with resection is necessary if total necrosis occurs. IV heparinization should be started peroperatively and continued for minimum 72 hours; oral anticoagulants should be used for 6 months. If hypercoagulability is detected, oral anticoagulants should be used for lifetime $\mathrm{e}^{3,7}$.

If early diagnosis is possible; interventional radiology can apply thrombolytics (streptokinase, urokinase, t-PA) through SMV locally ${ }^{3,7}$. The presented case 2 is an example of this scenario; early diagnosis, laparoscopic confirmation and in the absence of necrosis, percutaneous transhepatic access with thrombectomy was succesful with preservation of bowel. The patient was followed for a period of 9 months with no reccurence of SMV trombosis. When conservative treatments are administrated; wide-spectrum antibiotics should be applied to prevent bacterial translocation? ${ }^{7}$.
When diagnosis of MVT delays, it is not possible to preserve intestines; our case 1 and 3 had intestinal necrosis revealed at laparoscopic exploration, and the treatment were continued with small bowel resection in both cases. Wide resection of small intestine can cause complications such as short bowel syndrome, pulmonary embolism, sepsis. After resection, MVT can repeat in 6 months for $14 \%$ of time, our cases were followed for a period between 9-12 months without recurrence ${ }^{3}$.

\section{Conclusion}

Acute MVT has better prognosis than arterial thrombosis, especially when early diagnosis is available. Clinical suspicion is very important for diagnosis; physical examination and laboratory tests are nonspecific and can cause a delay in diagnosis. Newly developed radiological imaging techniques are highly sensitive for diagnosis of MVT. Interventional radiology can manage successfully the early diagnosed cases without necrosis. After the operation, the case will be followed in term of recurrence.

\section{References}

1. Hmoud B, Singaly AK, Kamat PS. Mesenteric Venous Thrombosis. J Clin Experiment Hepatol 2014;4(3):257-63.

2. Schoots IG, Koffeman GI, Legemate DA, Levi M, van Gulik TM. Systematic review of survival after acute mesenteric ischaemia according to disease aetiology. Br J Surg 2004;91:1727.

3. Goldberg MF, Kim HS. Treatment of Acute Superior Mesenteric Vein Thrombosis with Percutaneous Techniques. Am J Roentgenol 2003;181(5):1305-7.

4. Rendell JH, Ockner RK. Mesenteric Venous Thrombosis. Gastroenterology 1982;82:358-72.

5. Abdu RA, Zachour BJ, Dallis DJ. Mesenteric Venous Thrombosis 1911 to 1984 . Surgery 1987;101:363-88.

6. Pabinger I, Schneider B. Thrombotic risk in hereditary antithrombin III, protein $\mathrm{C}$, or protein $S$ deficiency. A cooperative, retrospective study. Gesellschaft fur Thromboseund Hamostaseforschung (GTH) study group on natural inhibitors. Arterioscler Thromb Vascol 1996;16:742-8.

7. Lang SA, Loss M, Wohlgemuth WA, Schlitt HJ. Clinical Management of Acute Portal/Mesenteric Vein Thrombosis. Gastrointestinal Med Surg 2014;30:394-400.

8. Singal AK, Kamath PS, Tefferi A. Mesenteric venous thrombosis. Mayo Clin Proc Mayo Clin 2013;88:285-94. 